\title{
PEMODELAN REGRESI NONPARAMETRIK SPLINE TRUNCATED PADA FAKTOR-FAKTOR YANG MEMPENGARUHI PERTUMBUHAN EKONOMI DI PROVINSI MALUKU
}

\author{
Nonparametric Regression Spline Truncated for Modeling Factors Influence \\ Economic Growth in Maluku Province
}

\author{
M. Y. Matdoan ${ }^{1 *}$, A. M. Balami ${ }^{2}$, M. W. Talakua ${ }^{3}$ \\ 1,2,3 Program Studi Statistika, Fakultas MIPA Universitas Pattimura \\ Jln. Ir. M. Putuhena, KampusUnpatti - Poka, Ambon, 97233, Provinsi Maluku, Indonesia \\ e-mail: yahya.matdoan@fmipa.unpatti.ac.id*
}

\begin{abstract}
Abstrak: Pertumbuhan ekonomi merupakan tolak ukur bagi keberhasilan pembangunan suatu daerah, terutama di bidang ekonomi. Tujuan pembangunan ekonomi di suatu daerah pada dasarnya adalah untuk meningkatkan kesejahteraan masyarakat. Pertumbuhan ekonomi di Provinsi Maluku mengalami peningkatan positif. Namun, masih ada kesenjangan antara kabupaten dan kota. Hal ini tidak dapat dipisahkan dari faktor-faktor yang mempengaruhi pertumbuhan ekonomi, sehingga perlu dilakukan pemdolean faktor-faktor tersebut dengan metode regresi nonparametrik spline truncated. Metode ini sangat tergantung pada nilai Generalized Cross-Validation (GCV) minimum. Hasil yang diperoleh dalam penelitian ini adalah persentase pertumbuhan ekonomi tertinggi di Provinsi Maluku yaitu di Kota Ambon dengan persentase 6,17\%, dan terendah berada di Kabupaten Seram Timur (SBT) dengan persentase $5,03 \%$. Selanjutnya, model terbaik diperoleh dengan menggunakan tiga knot dan nilai GCV 11,6, nilai $R^{2}$ 0,94 dan nilai MSE 0,005. Hal Ini berarti bahwa variabel yang digunakan dalam penelitian ini mempengaruhi pertumbuhan ekonomi sebesar $94 \%$. Sedangkan sisanya dipengaruhi oleh variabel lain di luar penelitian.
\end{abstract}

Kata Kunci: regresi, spline, generalized cross validation.

\begin{abstract}
Economic growth is a benchmark for the success of a region's development, especially in the economic field. The purpose of economic development in an area is basically to improve the welfare and prosperity of the community. Economic growth in Maluku Province experienced a positive increase. However, there is still a disparity between districts/cities in Maluku Province, which has an impact on increasing unemployment and an increasingly poor population. This is inseparable from the influencing factors so that it can be precisely done by modeling these factors using the truncated nonparametric spline regression method. the advantages of this method occur because in nonparametric spline truncated regression has knot points, which are joint fusion points that indicate changes in data behavior patterns. Besides, this method can be used to model data patterns that change at certain sub-intervals. The best model is very dependent on determining the optimal knot point by using the minimum Generalized CrossValidation $(G C V)$ value. The results obtained in this study were the highest percentage of economic growth in Maluku Province, Ambon City with a percentage of 6.17\%, and the lowest economic growth was in the East Seram District (SBT) with a percentage of 5.03\%. Furthermore, the best model is obtained with a model with three knots and a GCV value of 11.61, a value of 2 of 0.94 and an MSE value of 0.005. This means that statistically, the variables used in this study affect economic growth by $94 \%$. While the rest is influenced by other variables outside the research.
\end{abstract}

Keywords: regression, spline, generalized cross validation. 
Matdoan, dkk.| Pemodelan Regresi Nonparametrik Spline Truncated ...

\section{PENDAHULUAN}

Pertumbuhan ekonomi merupakan suatu tolak ukur bagi keberhasilan pembangunan suatu daerah, khususnya di bidang ekonomi. Suatu daerah memiliki yang memiliki peningkatan pertumbuhan ekonomi terus-menerus tiap tahunnya akan memajukan pembangunan di daerah tersebut. Tujuan dari pembangunan ekonomi di suatu daerah pada dasarnya adalah meningkatkan kesejahteraan dan kemakmuran masyarakat. Pertumbuhan ekonomi yang lambat dapat menyebabkan kekacauan politik, keamanan, dan sosial sehingga tentunya dapat mengganggu pertumbuhan dan pembangungan ekonomi serta menurunnya PDB suatu daerah.[9]

Pertumbuhan ekonomi di Provinsi Maluku tahun 2017 berada pada 5,6 persen dibandingkan dengan tahun sebelumnya. Pertumbhan ekonomi di Provinsi Maluku mengalami pertumbuhan positif, hal ini diukur berdasarkan Produk Domestik Regional Bruto (PDRB) atas dasar harga berlaku mencapai Rp 37,06 triliun. Pertumbuhan ekonomi di Provinsi Maluku dari tahun ke tahun mengalami peningkatan. Sampai dengan Triwulan II 2018, tercatat sebesar 5,47 persen. Namun, masih terjadi disparitas pertumbuhan ekonomi di beberapa daerah di Provinsi Maluku, sehingga tidak dapat menekan angka pengangguran dan kemiskinan [4].

Pengendalian pertumbuhan ekonomi di Provinsi Maluku diperlukan agar pertambahan jumlah penduduk miskin dan pengangguran dapat terkontrol. Oleh karena itu, dibutuhkan suatu metode statistika yang dapat menghasilkan model untuk mengetahui faktor-faktor apa saja yang yang memiliki pengaruh terhadap pertumbuhan ekonomi di Provinsi Maluku. Untuk mengetahui pola hubungan faktor-faktor yang mempengaruhi pertumbuhan ekonomi dapat dilakukan dengan menggunakan analisis regresi [1].

Analisis regresi merupakan sebuah analisa statistika yang digunakan untuk mengetahui pola hubungan antara satu atau lebih variabel. Variabel yang ada dalam analisis regresi terdiri atas variabel respon dan variabel prediktor. Untuk dapat memodelkan satu atau lebih variabel, pertama yang mestinya dilakukan adalah menyelidiki apakah variabel-variabel tersebut secara rasional berkorelasi atau tidak. Terdapat tiga jenis regresi yang dikembangkan oleh para peneliti yaitu regresi parametrik, regresi nonparametrik, dan regresi semiparametrik. Regresi parametrik yaitu regresi dimana bentuk pola kurva regresinya diketahui sedangkan regresi nonparametrik bentuk pola kurva regresinya tidak diketahui. Sementara itu, apabila sebagian bentuk pola kurva regresinya diketahui dan sebagian lagi tidak diketahui maka analisis regresi yang digunakan adalah regresi semiparametrik [3]. Umumnya dalam analisis regresi, sebelum melakukan pemodelan menggunakan salah satu dari ketiga jenis regresi, didahului dengan memeriksa scatter plot antara masing-masing variabel prediktor dengan variabel respon. Apabila scatter plot menunjukkan kecenderungan data mengikuti pola linear, kuadratik, kubik, atau polinomial maka digunakan model regresi parametrik [2]. Namun apabila scatter plot antara variabel prediktor dan variabel respon tidak menunjukkan kecenderungan data mengikuti suatu pola tertentu maka yang digunakan adalah model regresi nonparametrik [5].

Salah satu metode regresi nonparametrik yang dapat mengatasi pola data yang tidak jelas yaitu dengan menggunakan regresi nonparametrik spline truncated [6]. Model regresi nonparametrik spline truncated tidak memberikan asumsi terhadap bentuk kurva regresi atau diasumsikan mulus atau smooth [7]. Kelebihan metode ini terjadi karena dalam regresi spline truncated memiliki titik-titik knot, yaitu titik-perpaduan bersama yang menunjukkan terjadinya perubahan pola perilaku data. Selain itu, regresi nonparametrik spline truncated bisa memodelkan data pada pola data yang berubah-ubah pada sub-sub interval tertentu [8]. Karena metode ini merupakan salah satu jenis potongan polinomial, yaitu polinomial yang memiliki sifat tersegmen. Bentuk estimator regresi nonparametrik spline truncated juga dipengaruhi oleh lokasi dan banyaknya titik-titik knot [11]. Bentuk estimator regresi nonparamterik spline truncated sangat dipengaruhi oleh nilai parameter penghalus, jika nilai parameter penghalus sangat kecil maka akan memberikan estimator kurva regresi yang sangat kasar. Salah satu metode untuk memilih parameter penghalus yaitu diperoleh dari Generalized Cross Validation (GCV) yang paling minimum [12]. 


\section{METODE PENELITIAN}

\subsection{Sumber data dan Variabel Peneltian}

Data yang digunakan dalam penelitian ini adalah data sekunder yang diperoleh dari Badan Pusat Statistik (BPS) tahun 2017. Unit Obeservasi yang digunakan dalam penelitian ini adalah kabupaten/kota di Provinsi Maluku.

\subsection{Variabel Penelitian}

Variabel yang digunakan dalam peneltian ini diperoleh dari penelitian sebelumnya maupun teori yang berhubungan dengan pertumbuhan ekonomi. Variabel yang digunakan dapat dilihat pada Tabel 1.

Tabel 1. Variabel Penelitian

\begin{tabular}{ll}
\hline & \multicolumn{1}{c}{ Nama Variabel } \\
\hline $\mathrm{Y}_{1}=$ & Persentase Pertumbuhan Ekonomi \\
$\mathrm{X}_{1}=$ & Persentase Penduduk Miskin \\
$\mathrm{X}_{2}=$ & Persentase PDRB \\
$\mathrm{X}_{3}=$ Persentase Tingkat Pengangguran Tetap (TPT) \\
$\mathrm{X}_{4}=$ Persentase Ekspor \\
$\mathrm{X}_{5}=$ Persentase Pengeluaran Konsumsi Rumah Tangga \\
$\mathrm{X}_{6}=$ Persentase Pengeluaran Konsumsi Pemerintah \\
$\mathrm{X}_{7}=$ Persentase Koperasi Usaha Rakyat (KUR) \\
$\mathrm{X}_{8}=$ Persentase Bank Usaha Milik Desa (BUMD) \\
$\mathrm{X}_{9}=$ Persentase Program Indonesia Pintar (PIP) \\
$\mathrm{X}_{10}=$ Persentase Keluarga Sejahtera \\
$\mathrm{X}_{11}=$ Persentase Jaminan Kesehatan Masyarakat (Jamkesmas) \\
\hline
\end{tabular}

\subsection{Langkah Analisis}

Langkah-langkah yang dilakukan dalam penelitian ini adalah sebagai berikut [10].

a. Membuat gambaran umum tentang pertumbuhan ekonomi di Provinsi Maluku.

b. Membuat scatter plot antara variabel prediktor dengan variabel respon untuk mengetahui pola data.

c. Memodelkan persentase pertumbuhan ekonomi dan faktor-faktor yang mempengaruhinya dengan menggunakan spline linier 1 knot, 2 knot dan 3 knot.

d. Memilih titik knot optimal dengan menggunakan metode GCV dimana titik knot optimal berkaitan dengan GCV minimum.

e. Menghitung nilai koefisien determinasi ( $\left.R^{2}\right)$ dan Mean Squared Error (MSE).

f. Melakukan interpretasi model dan menarik kesimpulan.

\section{HASIL DAN PEMBAHASAN}

\subsection{Gambaran Umum}

Pertumbuhan ekonomi merupakan proses perubahan kondisi perekonomian suatu daerah secara berkesinambungan menuju keadaan yang lebih baik selama periode tertentu. Adanya pertumbuhan ekonomi merupakan indikasi keberhasilan pembangunan ekonomi dalam kehidupan masyarakat. Berikut pada Gambar 1 menunjukan data persentase pertumbuhan ekonomi di Provinsi Maluku pada tahun 2017. 


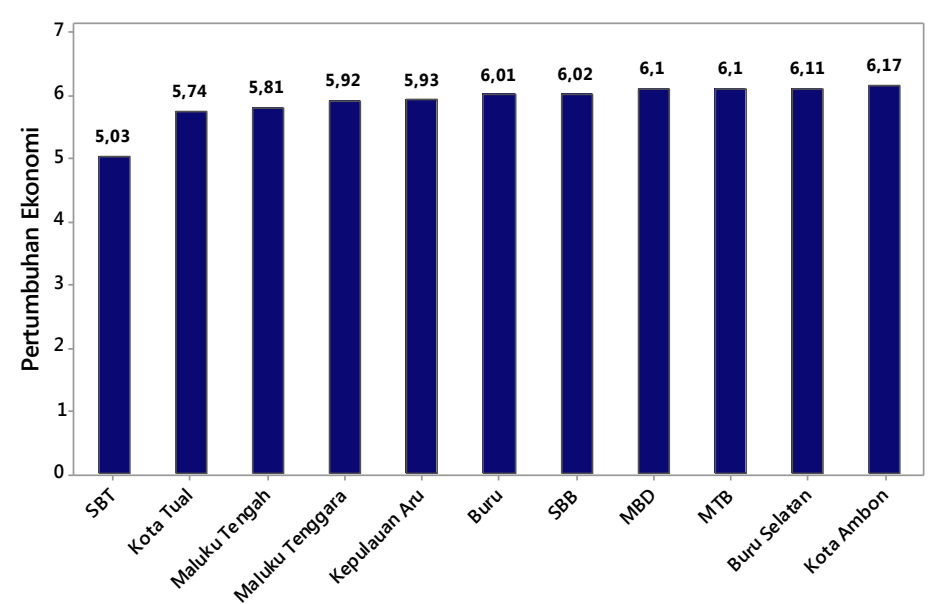

Gambar 1. Grafik Persentase Pertumbuhan Ekonomi

Berdasarkan Gambar 1, menunjukkan bahwa pada tahun 2017 persentase pertumbuhan ekonomi paling tinggi yaitu di Kota Ambon dengan Persentase sebesar 6,17\%, kemudian diikuti oleh Kabupaten Buru Selatan dengan persentase sebesar $6,11 \%$ persen. Sementara itu, Kabupaten/Kota yang memiliki persentase pertumbuhan ekonomi terendah yaitu di Kabupaten Seram Bagian Timur (SBT) dengan persentase sebesar 5,03\%. Selanjutnya pada Gambar 2 dapat dilihat scatter plot atau pola penyebaran data pertumbuhan ekonomi dengan faktor-faktor yang mempengaruhinya .

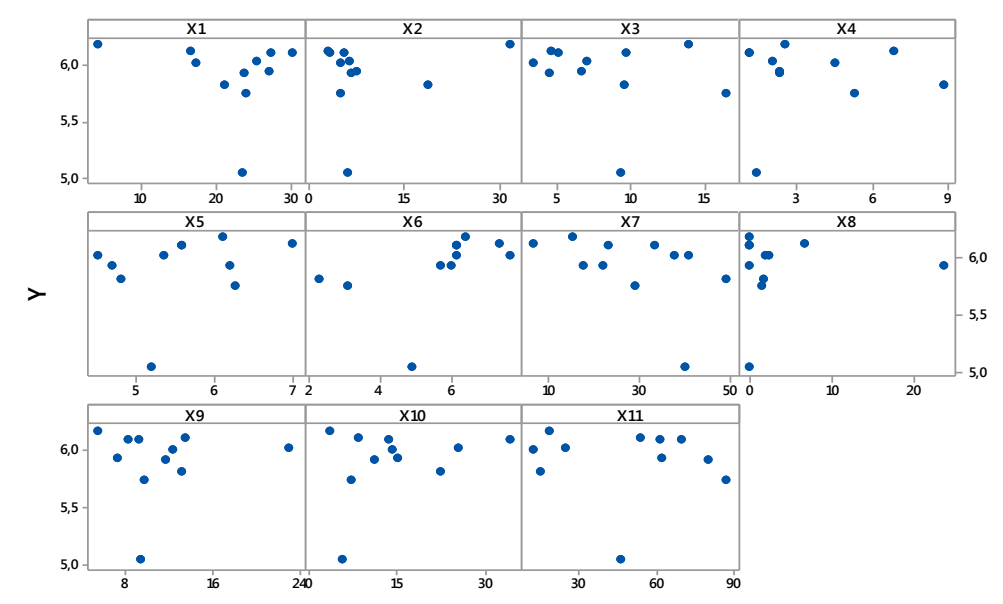

\section{Gambar 2. Scatter Plot Antara Variabel Respon dengan Variabel Prediktor}

Berdasarkan Gambar 2, menunjukan bahwa pola hubungan antara variabel pertumbuhan ekonomi (Y) dengan faktor-faktor yang mempengaruhinya (X) memiliki sebaran data menyebar dan tidak memiliki pola data tertentu.

\subsection{Memodelkan Pertumbuhan Ekonomi dengan Menggunakan Regresi Nonparamterik Spline Truncated}

Pembahasan ini akan dilakukan pemodelan mengenai pertumbuhan ekonomi di Provinsi Maluku. Metode yang digunakan untuk memodelkan data ini adalah metode regresi nonparametrik spline truncated. Titik knot merupakan titik dimana pola data berubah, titik knot yang digunakan dalam penelitian ini adalah satu knot, dua knot dan tiga knot. 


\subsubsection{Pemilihan Titik Knot Optimal Model Spline dengan Satu Knot}

Pemilihan titik knot optimal diawali dari satu titik knot. Dengan menggunakan satu titik knot dan GCV minimum pada variabel-variabel yang mempengaruhi pertumbuhan ekonomi. GCV minimum tersebut diharapkan dapat meghasilkan model regresi noparametrik spline truncated dengan satu titik knot pada kasus pertumbuhan ekonomi. Nilai GCV yang dihasilkan dari satu titik knot adalah sebagai berikut.

Tabel 2. Pemilihan Titik Optimal dengan Satu Titik Knot

\begin{tabular}{rrrrrrrrrrrr}
\hline$X_{1}$ & $X_{2}$ & $X_{3}$ & $X_{4}$ & $X_{5}$ & $X_{6}$ & $X_{7}$ & $X_{8}$ & $X_{9}$ & $X_{10}$ & $X_{11}$ & $G C V$ \\
\hline $\mathbf{6 , 0 3}$ & $\mathbf{4 , 7 4}$ & $\mathbf{4 , 2 0}$ & $\mathbf{1 , 6 6}$ & $\mathbf{4 , 6 7}$ & $\mathbf{2 , 6 2}$ & $\mathbf{9 . 1 5}$ & $\mathbf{1 , 4 5}$ & $\mathbf{6 , 7 5}$ & $\mathbf{1 , 5 5}$ & $\mathbf{1 6 , 7 6}$ & $\mathbf{2 1 , 9 9}$ \\
22,31 & 22,96 & 12,49 & 6,48 & 6,25 & 6,00 & 36,05 & 16,40 & 17,73 & 17,60 & 64,14 & 26,09 \\
24,93 & 25,89 & 13,83 & 7,26 & 6,50 & 6,54 & 40,39 & 18,81 & 19,50 & 20,19 & 71,78 & 29,93 \\
17,06 & 17,08 & 9,82 & 4,93 & 5,74 & 4,91 & 27,38 & 11,57 & 14,19 & 12,43 & 48,86 & 32,98 \\
26,51 & 27,66 & 14,63 & 7,73 & 6,65 & 6,87 & 43,00 & 20,25 & 20,56 & 21,75 & 76,36 & 36,14 \\
24,41 & 25,31 & 13,56 & 7,11 & 6,45 & 6,43 & 39,52 & 18,33 & 19,15 & 19,67 & 70,25 & 36,07 \\
\hline
\end{tabular}

Berdasarkan Tabel 2, dapat dilihat bahwa nilai GCV paling minimum adalah 21,99 dengan titik knot optimal adalah sebagai berikut:

$\mathrm{K}_{5}=6,03 ; \mathrm{K}_{2}=4,74 ; \mathrm{K}_{3}=4,20 ; \mathrm{K}_{4}=1,66 ; \mathrm{K}_{5}=4,67 ; \mathrm{K}_{6}=2,62 ; \mathrm{K}_{7}=9,15 ; \mathrm{K}_{8}=1,45 ; \mathrm{K}_{9}=6,75$; $\mathrm{K}_{10}=1,55 ; \mathrm{K}_{11}=16,76$.

Hasil ini akan dibandingkan dengan dua knot dan tiga knot. Perbandingan ini dilakukan untuk memperoleh model spline terbaik.

\subsubsection{Pemilihan Titik Knot Optimal Model Spline dengan Dua Knot}

Setelah memperoleh titik knot optimal dari satu titik knot maka selanjutnya mencari titik knot optimal dengan dua titik knot. Percobaan dilakukan dengan cara serupa dan dipilih GCV yang paling minimum. Lokasi dua titik knot dengan GCV minimum yang dihasilkan adalah 17,68 dengan titik knot optimal sebagai berikut:

$\mathrm{K}_{1}=7,08 ; \mathrm{K}_{2}=23,36 ; \mathrm{K}_{3}=5,92 ; \mathrm{K}_{4}=24,13 ; \mathrm{K}_{5}=4,74 ; \mathrm{K}_{6}=13,02 ; \mathrm{K}_{7}=1,97 ; \mathrm{K}_{8}=6,80 ; \mathrm{K}_{9}=4,77$; $\mathrm{K}_{10}=6,35 ; \mathrm{K}_{11}=2,83 ; \mathrm{K}_{12}=6,21 ; \mathrm{K}_{13}=10,89 ; \mathrm{K}_{14}=37,79 ; \mathrm{K}_{15}=2,41 ; \mathrm{K}_{16}=17,36 ; \mathrm{K}_{17}=7,46 ; \mathrm{K}_{18}=$ 18,$44 ; \mathrm{K}_{19}=2,59 ; \mathrm{K}_{20}=18,64 ; \mathrm{K}_{21}=19,82 ; \mathrm{K}_{22}=67,19$.

\subsubsection{Pemilihan Titik Knot Optimal Model Spline dengan Tiga Knot}

Setelah memperoleh titik knot optimal dari satu titik knot dan dua titik knot, maka selanjutnya mencari titik knot optimal dengan tiga titik knot. Percobaan dilakukan dengan cara serupa dan dipiih GCV yang paling minimum. Lokasi tiga titik knot dengan GCV minimum yang dihasilkan adalah 11,61 dengan titik knot optimal sebagai berikut:

$\mathrm{K}_{1}=5,51 ; \mathrm{K}_{2}=27,55 ; \mathrm{K}_{3}=29,65 ; \mathrm{K}_{4}=4,15 ; \mathrm{K}_{5}=28,83 ; \mathrm{K}_{6}=31,18 ; \mathrm{K}_{7}=3,93 ; \mathrm{K}_{8}=15,16 ; \mathrm{K}_{9}=$ 16,$23 ; \mathrm{K}_{10}=1,50 ; \mathrm{K}_{11}=8,04 ; \mathrm{K}_{12}=8,66 ; \mathrm{K}_{13}=4,62 ; \mathrm{K}_{14}=6,75 ; \mathrm{K}_{15}=6,96 ; \mathrm{K}_{16}=2,51 ; \mathrm{K}_{17}=7,09$; $\mathrm{K}_{18}=7,52 ; \mathrm{K}_{19}=8,28 ; \mathrm{K}_{20}=44,73 ; \mathrm{K}_{21}=48,20 ; \mathrm{K}_{22}=0,96 ; \mathrm{K}_{23}=21,22 ; \mathrm{K}_{24}=23,15 ; \mathrm{K}_{25}=6,40 ; \mathrm{K}_{26}=$ 21,$27 ; K_{27}=22,68 ; K_{28}=1,03 ; K_{29}=22,78 ; K_{30}=24,85 ; K_{31}=25,24 ; K_{32}=79,41 ; K_{33}=85,53$.

\subsubsection{Perbandingan GCV Minimum dan Banyaknya Titik Knot Optimum}

Perbandingan GCV minimum model dengan satu titik knot, dua titik knot, dan model dengan tiga titik knot ditunjukkan pada Tabel 3. Yang menunjukkan bahwa model terbaik adalah model spline truncated dengan tiga titik knot dengan nilai GCV sebesar 11,61. Selain itu, diperoleh nilai MSE sebesar 0,005 dan $R^{2}$ sebesar 0,94 . Hal ini menunjukan bahwa model yang diperoleh dapat menjelaskan pertumbuhan ekonomi sebesar $94 \%$. 


\begin{tabular}{ccc}
\multicolumn{3}{c}{ Tabel 3. Perbandingan GCV Optimum } \\
\hline No & Model & GCV \\
\hline 1 & 1 Titik Knot & 21,99 \\
2 & 2 Titik Knot & 17,68 \\
3 & 3 Titik Knot & 11,61 \\
\hline
\end{tabular}

\subsubsection{Interpretasi Model Regresi Spline Truncated} knot yaitu:

Berdasarkan hasil perbandingan GCV optimum, maka diperoleh model terbaik dengan tiga titik

$$
\begin{aligned}
\hat{y}= & 0,013+0,022 x_{1}+0,096\left(x_{1}-5,51\right)_{+}^{1}-0,12\left(x_{1}-27,55\right)_{+}^{1}+0,06\left(x_{1}-29,65\right)_{+}^{1}+0,07 x_{2}+0,21\left(x_{2}-4,15\right)_{+}^{1}+ \\
& 0,10\left(x_{2}-28,83\right)_{+}^{1}-0,002\left(x_{2}-31,18\right)_{+}^{1}+0,06 x_{3}-0,02\left(x_{3}-3,93\right)_{+}^{1}-0,001\left(x_{3}-15,16\right)_{+}^{1}-0,03\left(x_{3}-16,23\right)_{+}^{1}+ \\
& 0,14 x_{4}+0,02\left(x_{4}-1,50\right)_{+}^{1}+0,48\left(x_{4}-8,04\right)_{+}^{1}+0,06\left(x_{4}-8,66\right)_{+}^{1}+0,01 x_{5}-0,12\left(x_{5}-4,62\right)_{+}^{1}+0,03\left(x_{5}-6,75\right)_{+}^{1}+ \\
& 0,01\left(x_{5}-6,96\right)_{+}^{1}+0,08 x_{6}-0,01\left(x_{6}-2,51\right)_{+}^{1}-0,001\left(x_{6}-7,09\right)_{+}^{1}+0,01\left(x_{6}-7,52\right)_{+}^{1}-0,01 x_{7}-0,001\left(x_{7}-8,28\right)_{+}^{1}+ \\
& 0,18\left(x_{7}-44,73\right)_{+}^{1}-0,01\left(x_{7}-48,20\right)_{+}^{1}-0,001 x_{8}+0,05\left(x_{8}-0,96\right)_{+}^{1}+0,05\left(x_{8}-21,22\right)_{+}^{1}-0,01\left(x_{8}-23,15\right)_{+}^{1}+0,06 x_{9}+ \\
& 0,003\left(x_{9}-21,27\right)_{+}^{1}+0,01\left(x_{9}-22,68\right)_{+}^{1}+0,20 x_{10}+0,004\left(x_{10}-1,03\right)_{+}^{1}+0,02\left(x_{10}-24,85\right)_{+}^{1}+0,03\left(x_{10}-15,24\right)_{+}^{1}- \\
& 0,005 x_{11}+0,04\left(x_{11}-79,41\right)_{+}^{1}+0,19\left(x_{11}-82,24\right)_{+}^{1}+0,04\left(x_{11}-85,53\right)_{+}^{1}
\end{aligned}
$$

Model diatas dapat diinterpretasikan sebagai berikut.

1) Apabila variabel $x_{2}, x_{3}, x_{4}, x_{5}, x_{6}, x_{7}, x_{8}, x_{9}, x_{10}$ dan $x_{11}$ dianggap konstan, maka besar pengaruh persentase penduduk miskin $\left(x_{1}\right)$ terhadap pertumbuhan ekonomi $(y)$ adalah :

$$
\begin{gathered}
\hat{y}=0,022 x_{1}+0,096\left(x_{1}-5,51\right)_{+}^{1}-0,12\left(x_{1}-27,55\right)_{+}^{1}+0,06\left(x_{1}-29,65\right)_{+}^{1} \\
\hat{y}= \begin{cases}0,022 x_{1} ; & x_{1}<5,51 \\
-0,51 x_{1}+0,12 ; & 5,51 \leq x_{1}<27,55 \\
-, 0,73 x_{1}-0,002 ; & 27,55 \leq x_{1}<29,65 \\
-1,01 x_{1}+0,06 ; & x_{1} \geq 29,65\end{cases}
\end{gathered}
$$

Berdasarkan model tersebut, dapat diinterpretasikan yaitu apabila persentase penduduk miskin antara $5,51 \%$ hingga $27,55 \%$ dan persentase penduduk miskin ini naik $1 \%$ maka pertumbuhan ekonomi akan cenderung turun sebesar 0,51 . Selanjutnya jika persentase penduduk miskin antara 27,55\% sampai $29,65 \%$ dan persentase penduduk miskin naik $1 \%$ maka pertumbuhan ekonomi akan cenderung turun sebesar 0,73. Apabila persentase penduduk miskin lebih dari $29,65 \%$ dan jika persentase penduduk miskin naik $1 \%$ maka pertumbuhan ekonomi akan turun sebesar 1,01.

2) Apabila variabel $x_{1}, x_{3}, x_{4}, x_{5}, x_{6}, x_{7}, x_{8}, x_{9}, x_{10}$ dan $x_{11}$ dianggap konstan, maka pengaruh persentase PDRB $\left(x_{2}\right)$ terhadap pertumbuhan ekonomi $(y)$ adalah

$$
\begin{gathered}
\hat{y}=0,07 x_{2}+0,21\left(x_{2}-4,15\right)_{+}^{1}+0,10\left(x_{2}-28,83\right)_{+}^{1}-0,002\left(x_{2}-231.18\right)_{+}^{1} \\
\hat{y}= \begin{cases}0,021 x_{2} ; & x_{2}<4,15 \\
0,31 x_{2}-0,53 ; & 4,15 \leq x_{2}<28,83 \\
0,19 x_{2}+2,78 ; & 28,83 \leq x_{2}<31,18 \\
0,25 x_{2}+0,10 ; & x_{2} \geq 31,18\end{cases}
\end{gathered}
$$


Berdasarkan model tersebut, dapat diinterpretasikan yaitu apabila persentase PDRB antara 4,15\% sampai $28,83 \%$ dan apabila persentase PDRB naik $1 \%$ maka pertumbuhan ekonomi akan naik sebesar 0,31. Selanjutnya jika persentase PDRB antara 28,83 hingga 31,18 dan apabila persentase PDRB naik $1 \%$ maka pertumbuhan ekonomi naik sebesar 0,19. Apabila persentase PDRB lebih dari 29,65\% maka pertumbuhan ekonomi akan naik sebesar 0,25 .

3) Apabila variabel $x_{1}, x_{2}, x_{4}, x_{5}, x_{6}, x_{7}, x_{8}, x_{9}, x_{10}$ dan $x_{11}$ dianggap konstan, maka pengaruh persentase TPT $\left(x_{3}\right)$ terhadap pertumbuhan ekonomi $(y)$ adalah:

$$
\begin{gathered}
\hat{y}=0,06 x_{3}-0,02\left(x_{3}-3,93\right)_{+}^{1}-0,001\left(x_{3}-15,16\right)_{+}^{1}-0,03\left(x_{3}-16,23\right)_{+}^{1} \\
\hat{y}= \begin{cases}0,06 x_{3} ; & x_{3}<3.93 \\
-0,04 x_{3}-0,07 ; & 3,93 \leq x_{3}<15,16 \\
-0,04 x_{3}+0,09 ; & 15,16 \leq x_{3}<16,23 \\
0,009 x_{3}+0,58 ; & x_{3} \geq 16,23\end{cases}
\end{gathered}
$$

Berdasarkan model tersebut, dapat diinterpretasikan yaitu apabila persentase TPT antara 3,93\% hingga $15,16 \%$ dan persentase TPT naik $1 \%$ maka pertumbuhan ekonomi akan turun sebesar 0,04 . Selanjutnya apabila persentase TPT antara $15,16 \%$ sampai $16,23 \%$ dan persentase TPT naik $1 \%$ maka pertumbuhan ekonomi akan turun sebesar 0,04\%. Apabila persentase TPT lebih dari 16,23\% dan persentase TPT naik $1 \%$, maka pertumbuhan ekonomi akan naik sebesar 0,009 .

4) Apabila variabel $x_{1}, x_{2}, x_{3}, x_{5}, x_{6}, x_{7}, x_{8}, x_{9}, x_{10}$ dan $x_{11}$ dianggap konstan, maka pengaruh persentase ekspor $\left(x_{4}\right)$ terhadap pertumbuhan ekonomi $(y)$ adalah:

$$
\begin{gathered}
\hat{y}=0,14 x_{4}+0,02\left(x_{4}-1,50\right)_{+}^{1}+0,48\left(x_{4}-8,04\right)_{+}^{1}+0,06\left(x_{4}-8,66\right)_{+}^{1} \\
\hat{y}= \begin{cases}0,14 x_{4} ; & x_{4}<1,50 \\
0,16 x_{4}-0,03 ; & 1,50 \leq x_{4}<8,04 \\
0,64 x_{4}-3,89 ; & 8,04 \leq x_{4}<8,66 \\
0,7 x_{4}-4,4 ; & x_{4} \geq 8,66\end{cases}
\end{gathered}
$$

Berdasarkan model tersebut, dapat diinterpretasikan yaitu apabila persentase ekspor antara 1,50\% hingga $8,04 \%$ dan persentase ekspor naik $1 \%$ maka pertumbuhan ekonomi naik sebesar 0,16. Selanjutnya jika persentase ekspor antara $8,04 \%$ sampai $8,66 \%$ dan persentase ekspor naik $1 \%$, maka pertumbuhan ekonomi akan naik 0,64. Apabila ekspor lebih dari 8,66\% dan persentase ekspor naik $1 \%$ maka pertumbuhan ekonomi akan naik 0,7 .

5) Apabila variabel $x_{1}, x_{2}, x_{3}, x_{4}, x_{6}, x_{7}, x_{8}, x_{9}, x_{10}$ dan $x_{11}$ dianggap konstan, maka pengaruh persentase PKRT $\left(x_{5}\right)$ terhadap pertumbuhan ekonomi $(y)$ adalah:

$$
\begin{gathered}
\hat{y}=0,01 x_{5}-0,12\left(x_{5}-4,62\right)_{+}^{1}+0,03\left(x_{5}-6,75\right)_{+}^{1}+0,01\left(x_{5}-6,96\right)_{+}^{1} \\
\hat{y}= \begin{cases}0,01 x_{5} ; & x_{5}<4,62 \\
-0,11 x_{5}+0,55 ; & 4,62 \leq x_{5}<6,75 \\
-0,08 x_{5}+0,35 ; & 6,75 \leq x_{5}<6,96 \\
-0,07 x_{5}+0,28 ; & x_{5} \geq 6,96\end{cases}
\end{gathered}
$$


Berdasarkan model tersebut, jika persentase PKRT antara 4,62\% hingga 6,75\% dan persentase PKRT naik $1 \%$, maka pertumbuhan ekonomi akan menurun sebanyak 0,11 . Selanjutnya apabila persentase PKRT antara 6,75\% sampai 6,96\% dan persentase PKRT naik 1\% maka pertumbuhan ekonomi akan turun sebesar 0,08. Apabila persentase PKRT lebih dari 6,96\% dan persentase PKRT naik 1\% maka pertumbuhan ekonomi akan turun sebesar 0,07.

6) Apabila variabel $x_{1}, x_{2}, x_{3}, x_{4}, x_{6}, x_{7}, x_{8}, x_{9}, x_{10}$ dan $x_{11}$ dianggap konstan, maka pengaruh persentase PKP $\left(x_{6}\right)$ terhadap pertumbuhan ekonomi $(y)$ adalah:

$$
\begin{gathered}
\hat{y}=0,08 x_{6}-0,01\left(x_{6}-2,51\right)_{+}^{1}+0,001\left(x_{6}-7,09\right)_{+}^{1}+0,01\left(x_{6}-7,52\right)_{+}^{1} \\
\hat{y}= \begin{cases}0,08 x_{6} ; & x_{6}<2,51 \\
0,07 x_{6}+0,25 ; & 2,51 \leq x_{6}<7,09 \\
0,07 x_{6}+0,03 ; & 7,09 \leq x_{6}<7,52 \\
0,08 x_{6}+0,04 ; & x_{6} \geq 7,52\end{cases}
\end{gathered}
$$

Berdasarkan model tersebut, dapat diinterpretasikan yaitu apabila persentase PKP antara 2,51\% hingga $7,09 \%$ dan persentase PKP naik $1 \%$ maka pertumbuhan ekonomi naik sebesar 0,007 . Selanjutnya apabila persentase PKP antara 7,09\% hingga 7,52\% dan persentasi PKP naik 1\% maka pertumbuhan ekonomi naik sebesar 0,07. Apabila persentase PKP lebih dari 7,52\% dan persentase PKP naik $1 \%$ maka pertumbuhan ekonomi naik 0,08 .

7) Apabila variabel $x_{1}, x_{2}, x_{3}, x_{4}, x_{5}, x_{6}, x_{8}, x_{9}, x_{10}$ dan $x_{11}$ dianggap konstan, maka pengaruh persentase KUR $\left(x_{7}\right)$ terhadap pertumbuhan ekonomi $(y)$ adalah:

$$
\begin{gathered}
\hat{y}=0,01 x_{7}-0,001\left(x_{7}-8,28\right)_{+}^{1}+0,18\left(x_{7}-44,73\right)_{+}^{1}-0,01\left(x_{7}-48,20\right)_{+}^{1} \\
\hat{y}= \begin{cases}-0,01 x_{7} ; & x_{7}<8,28 \\
-0,01 x_{7}+0,01 ; & 8,28 \leq x_{7}<44,73 \\
0,17 x_{7}-8,04 ; & 44,73 \leq x_{7}<48,20 \\
0,16 x_{7}-7,6 ; & x_{7} \geq 48,20\end{cases}
\end{gathered}
$$

Berdasarkan model tersebut, dapat diinterpretasikan yaitu apabila persentase KUR antara 8,28\% hingga 44,73\% dan persentase KUR naik $1 \%$ maka pertumbuhan ekonomi turun sebesar 0,01. Selanjutnya jika persentase KUR antara $44,73 \%$ sampai $48,73 \%$ dan persentase KUR naik $1 \%$ maka pertumbuhan ekonomi naik 0,17. Apabila persentase KUR lebih dari 48,20\% dan persentase KUR naik $1 \%$, maka pertumbuhan ekonomi naik 0,16 .

8) Apabila variabel $x_{1}, x_{2}, x_{3}, x_{4}, x_{5}, x_{6}, x_{7}, x_{9}, x_{10}$ dan $x_{11}$ dianggap konstan, maka pengaruh persentase bumdes $\left(x_{8}\right)$ terhadap pertumbuhan ekonomi $(y)$ adalah:

$$
\begin{gathered}
\hat{y}=0,001 x_{8}+0,05\left(x_{8}-0,96\right)_{+}^{1}+0,05\left(x_{8}-21,22\right)_{+}^{1}-0,01\left(x_{8}-23,15\right)_{+}^{1} \\
\hat{y}= \begin{cases}-0,001 x_{8} ; & x_{8}<0,96 \\
0,05 x_{8}-0,05 ; & 0,96 \leq x_{8}<21,22 \\
0,1 x_{8}-1,1 ; & 21,22 \leq x_{8}<23,15 \\
0,1 x_{8}-1,1 ; & x_{8} \geq 23,15\end{cases}
\end{gathered}
$$


Berdasarkan model tersebut, dapat diinterpretasikan yaitu apabila persentase bumdes antara 0,96\% hingga $21,22 \%$ dan persentase bumdes naik $1 \%$, maka pertumbuhan ekonomi naik 0,05 . Selanjutnya apabila persentase bumdes antara $21,22 \%$ hingga $23,15 \%$ dan persentase bumdes naik $1 \%$, maka pertumbuhan ekonomi naik 0,1 . Jika persentase bumdes lebih dari $23,15 \%$ dan persentase bumdes naik $1 \%$, maka pertumbuhan ekonomi naik 0,1 .

9) Apabila variabel $x_{1}, x_{2}, x_{3}, x_{4}, x_{5}, x_{6}, x_{7}, x_{8}, x_{10}$ dan $x_{11}$ dianggap konstan, maka pengaruh PIP $\left(x_{9}\right)$ terhadap pertumbuhan ekonomi $(y)$ adalah:

$$
\begin{gathered}
\hat{y}=0,06 x_{9}+0,003\left(x_{9}-6,40\right)_{+}^{1}-0,001\left(x_{9}-21,27\right)_{+}^{1}+0,01\left(x_{9}-22,68\right)_{+}^{1} \\
\hat{y}= \begin{cases}0,06 x_{9} ; & x_{9}<6,40 \\
0,06 x_{9}-0,02 ; & 6,40 \leq x_{9}<21,27 \\
0,06 x_{9}+0,002 ; & 21,27 \leq x_{9}<22,68 \\
0,07 x_{9}-0,22 ; & x_{9} \geq 22,68\end{cases}
\end{gathered}
$$

Berdasarkan model tersebut, dapat diinterpretasikan bahwa apabila PIP antara 6,40\% hingga 21,27\% dan PIP naik $1 \%$ maka pertumbuhan ekonomi akan naik sebesar 0,06. Selanjutnya jika PIP antar $21,27 \%$ sampai $22,68 \%$ dan persentase PIP naik 1\%, maka pertumbuhan ekonomi naik 0,06. Apabila PIP lebih dari $22,68 \%$ dan persentase PIP naik $1 \%$ maka pertumbuhan ekonomi meningkat sebanyak 0,07 .

10) Apabila variabel $x_{1}, x_{2}, x_{3}, x_{4}, x_{5}, x_{6}, x_{7}, x_{8}, x_{9}$ dan $x_{11}$ dianggap konstan, maka pengaruh persentase KKS $\left(x_{10}\right)$ terhadap pertumbuhan ekonomi $(y)$ adalah:

$$
\begin{gathered}
\hat{y}=0,020 x_{10}+0,004\left(x_{10}-1,03\right)_{+}^{1}+0,02\left(x_{10}-24,85\right)_{+}^{1}+0,03\left(x_{10}-25,24\right)_{+}^{1} \\
\hat{y}= \begin{cases}0,02 x_{10} ; & x_{10}<1,03 \\
0,2 x_{10}-0,004 ; & 1,03 \leq x_{9}<24,85 \\
0,2 x_{10}-0,5 ; & 24,85 \leq x_{9}<25,24 \\
0,2 x_{10}-0,9 ; & x_{9} \geq 25,24\end{cases}
\end{gathered}
$$

Berdasarkan model tersebut, dapat diinterpretasikan bahwa apabila persentase KKS antara 1,03\% hingga $24,85 \%$ dan persentase KKS naik $1 \%$ maka pertumbuhan ekonomi naik 0,2. Selanjutnya apabila persentase KKS antara $24,85 \%$ hingga $25,24 \%$ dan persentase KKS naik $1 \%$, maka pertumbuhan ekonomi meningkat 0,2. Jika persentase KKS lebih dari 25,24\% dan persentasse KKS naik $1 \%$, maka pertumbuhan ekonomi meningkat 0,2 .

11) Apabila variabel $x_{1}, x_{2}, x_{3}, x_{4}, x_{5}, x_{6}, x_{7}, x_{8}, x_{9}$ dan $x_{10}$ dianggap konstan, maka pengaruh persentase Jamkesmas $\left(x_{11}\right)$ terhadap pertumbuhan ekonomi $(y)$ adalah:

$$
\begin{gathered}
\hat{y}=0,005 x_{11}+0,04\left(x_{11}-79,41\right)_{+}^{1}+0,19\left(x_{11}-82,24\right)_{+}^{1}+0,04\left(x_{11}-85,53\right)_{+}^{1} \\
\hat{y}= \begin{cases}-0,005 x_{11} ; & x_{11}<79,41 \\
0,03 x_{11}-3,2 ; & 79,41 \leq x_{11}<82,24 \\
0,22 x_{11}-18,8 ; & 82,24 \leq x_{11}<85,53 \\
0,26 x_{11}-22,2 ; & x_{11} \geq 85,53\end{cases}
\end{gathered}
$$


Matdoan, dkk. Pemodelan Regresi Nonparametrik Spline Truncated ...

Berdasarkan model tersebut dapat diinterpretsikan bahwa apabila persentase Jamkesmas antara 79,41\% hingga 82,24\% dan persentase Jamkesmas naik 1\%, maka pertumbuhan ekonomi naik sebesar 0,03 . Selanjutnya jika persentase Jamkesmas antara $82,24 \%$ sampai $85,53 \%$ dan persentase Jamkesmas naik $1 \%$, maka pertumbuhan ekonomi naik 0,22. Apabila persentase Jamkesmas lebih dari 85,53\%, dan persentase Jamkesmas naik 1\%, maka pertumbuhan ekonomi naik 0,26.

\section{KESIMPULAN}

Berdasarkan hasil dan pembahasan maka diperoleh kesimpulan sebagai berikut:

1) Perkembangan Persentase pertumbuhan ekonomi di Provinsi Maluku tertiggi yaitu di Kota Ambon dengan persentase sebesar 6,17\%, kemudian diikuti oleh Kabupaten Buru Selatan dengan prsentase sebesar 6,11\%. Sementara itu Kabupaten/Kota yang memiliki Persentase pertumbuhan ekonomi terendah yaitu di Kabupaten Seram Bagian Timur (SBT) dengan Persentase sebesar 5,03\%.

2) Model regresi nonparametrik spline truncated terbaik yaitu dengan tiga titik knot diperoleh nilai GCV yaitu 11,61 dan $R^{2}$ sebesar 0,94 serta MSE sebesar 0,005. Artinya bahwa secara statistik variabel yang digunakan dalam penelitian berpengaruh terhadap kemiskinan sebesar $94 \%$. sedangkan sisanya dipengaruhi oleh variabel lain diluar penelitian. Selanjutnya diperoleh model regresi nonparametrik spline truncated terbaik yaitu:

$$
\begin{aligned}
\hat{y}= & 0,013+0,022 x_{1}+0,096\left(x_{1}-5,51\right)_{+}^{1}-0,12\left(x_{1}-27,55\right)_{+}^{1}+0,06\left(x_{1}-29,65\right)_{+}^{1}+0,07 x_{2}+0,21\left(x_{2}-4,15\right)_{+}^{1}+ \\
& 0,10\left(x_{2}-28,83\right)_{+}^{1}-0,002\left(x_{2}-31,18\right)_{+}^{1}+0,06 x_{3}-0,02\left(x_{3}-3,93\right)_{+}^{1}-0,001\left(x_{3}-15,16\right)_{+}^{1}-0,03\left(x_{3}-16,23\right)_{+}^{1}+ \\
& 0,14 x_{4}+0,02\left(x_{4}-1,50\right)_{+}^{1}+0,48\left(x_{4}-8,04\right)_{+}^{1}+0,06\left(x_{4}-8,66\right)_{+}^{1}+0,01 x_{5}-0,12\left(x_{5}-4,62\right)_{+}^{1}+0,03\left(x_{5}-6,75\right)_{+}^{1}+ \\
& 0,01\left(x_{5}-6,96\right)_{+}^{1}+0,08 x_{6}-0,01\left(x_{6}-2,51\right)_{+}^{1}-0,001\left(x_{6}-7,09\right)_{+}^{1}+0,01\left(x_{6}-7,52\right)_{+}^{1}-0,01 x_{7}-0,001\left(x_{7}-8,28\right)_{+}^{1}+ \\
& 0,18\left(x_{7}-44,73\right)_{+}^{1}-0,01\left(x_{7}-48,20\right)_{+}^{1}-0,001 x_{8}+0,05\left(x_{8}-0,96\right)_{+}^{1}+0,05\left(x_{8}-21,22\right)_{+}^{1}-0,01\left(x_{8}-23,15\right)_{+}^{1}+0,06 x_{9}+ \\
& 0,003\left(x_{9}-21,27\right)_{+}^{1}+0,01\left(x_{9}-22,68\right)_{+}^{1}+0,20 x_{10}+0,004\left(x_{10}-1,03\right)_{+}^{1}+0,02\left(x_{10}-24,85\right)_{+}^{1}+0,03\left(x_{10}-15,24\right)_{+}^{1}- \\
& 0,005 x_{11}+0,04\left(x_{11}-79,41\right)_{+}^{1}+0,19\left(x_{11}-82,24\right)_{+}^{1}+0,04\left(x_{11}-85,53\right)_{+}^{1}
\end{aligned}
$$

\section{DAFTAR PUSTAKA}

[1] Eubank, Spline Smoothing and Nonparametric Regression, New York: Marcel Dekker , 1988.

[2] I. N. Budiantara, Spline dalam Regresi Nonparametrik: Sebuah Pemodelan Statistika Masa Kini dan Masa Mendatang., Surabaya: Jurusan Statistika, Fakultas Matemetika dan Ilmu Pengetahuan Alam, Institut Teknologi Sepuluh Nopember., 2009.

[3] W. Hardle, Applied Nonparametric Regression, Cambridge University, 1990.

[4] BPS, Produk Domestik Regional Bruto Provinsi Maluku 2015, Ambon, 2015.

[5] J. d. Y. L. Wang, "Polynomial Spline Confidence Bands For Regression Curves," vol. Statistica Sinica, no. 19, pp. 325-342, 2009.

[6] N. Ghaida, "Pemodelan regresi spline menggunakan metode penalized spline pada data longitudinal," Jurnal Gaussian Universitas Diponegoro, vol. 6, no. 2, pp. 221-230, 2017.

[7] D. Gujarati, Ekonometrika Dasar, Jakarta: Erlangga, 1978.

[8] F. Khairani, Aplikasi Spline Truncated dalam regresi nonparametrik, Medan: Skripsi Fakultas Matematika dan Ilmu Pengetahuan Alam, Universitas Sumateara Utara, 2015.

[9] Badan Pusat Statistik, Statistik Kesejahteraan Rakyat 2012, Jakarta, 2013. 
[10] N. Fitriyani, Metode Cross Validation dan Generalized Cross Validation dalam Regresi Nonparametrik Spline (Studi Kasus Data Fertilitas di Jawa Timur), Surabaya: Tesis Program Magister, Institut Teknologi Sepuluh Nopember, 2014.

[11] G. Wahba, Spline Models for Observation Data, Pensylvania: University of Winsconsin , 1990.

[12] J. Wang, Nonparametric Regression Analysis of Longitudinal Data, Davis: Departmen of Statistics, University of California, 2003. 